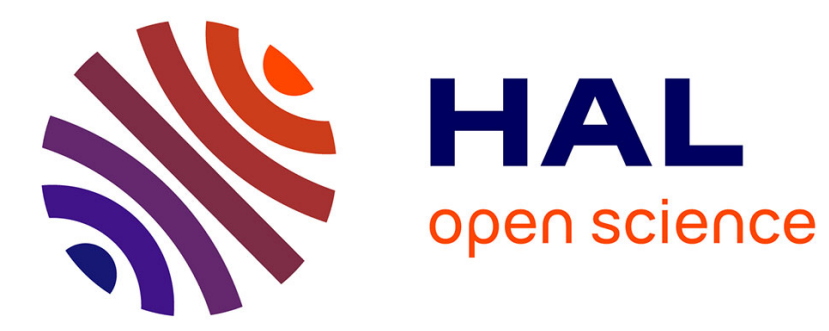

\title{
Application of X-ray tomography to evaluate liming impact on earthworm burrowing activity in an acidic forest soil under laboratory conditions
}

\author{
A. Auclerc, Yvan Capowiez, F. Guerold, J. Nahmani
}

\section{- To cite this version:}

A. Auclerc, Yvan Capowiez, F. Guerold, J. Nahmani. Application of X-ray tomography to evaluate liming impact on earthworm burrowing activity in an acidic forest soil under laboratory conditions. Geoderma, 2013, 202, pp.45-50. 10.1016/j.geoderma.2013.03.011 . hal-01080683

\section{HAL Id: hal-01080683 https://hal.science/hal-01080683}

Submitted on 29 May 2020

HAL is a multi-disciplinary open access archive for the deposit and dissemination of scientific research documents, whether they are published or not. The documents may come from teaching and research institutions in France or abroad, or from public or private research centers.
L'archive ouverte pluridisciplinaire HAL, est destinée au dépôt et à la diffusion de documents scientifiques de niveau recherche, publiés ou non, émanant des établissements d'enseignement et de recherche français ou étrangers, des laboratoires publics ou privés. 
Version définitive du manuscrit publiée dans / Final version of the manuscript published in:

Geoderma (2012), Vol. 202, p. 45-50, DOI: 10.1016/j.geoderma.2013.03.011

Journal homepage: www.elsevier.com/locate/geoderma

\section{Introduction}

In the 1980s, important forest decline was observed in numerous sensitive regions throughout the Northern hemisphere due to acidic atmospheric depositions caused by human activities (Campbell and Lee, 1996; Driscoll et al., 2001). Acidic atmospheric deposition can decrease forest soil $\mathrm{pH}$, indirectly induce earthworm abundance, and allow their replacement by enchytraeids in acidic soils (Edwards and Bohlen 1996; Graefe and Beylich, 2003; Räty and Huhta, 2004). To counteract increasing soil acidity and forest dieback, many European countries conducted large-scale liming (Hüttl and Zöttl, 1993; Formanek and Vranova, 2002; Godbold, 2003). Several studies showed an increase of earthworm populations following forest liming (Kreutzer, 1995; Theenhaus and Schaefer, 1995; Deleporte and Tillier, 1999; Potthoff et al., 2008). Similarly, the introduction of Lumbricus terrestris, an epi-anecic species (Judas et al. 1997) and of the endogeic earthworm Aporrectodea caliginosa (Robinson et al. 1996) in limed acidic forest lead to the establishment of reproducing populations.

Despite the roles of earthworm species play in many soil processes (Lavelle et al., 2006), to our knowledge, few studies have addressed the impact of forest liming on earthworm activity (Springett and Syers, 1984; Robinson et al., 1991; Judas et al., 1997; Auclerc et al., 2011). By ingesting soil, fragmenting organic matter, mixing and ejecting casts above and below ground (i.e. casting and burrowing activities), earthworms increase nutrient cycling and microbial activity in organic and mineral soil horizons (Jones et al., 1994; Shipitalo and Le Bayon, 2004; Lavelle et al., 2006). It is, however, difficult to study earthworm behaviour directly under field conditions because of the complex interactions between abiotic and biotic factors. Therefore, repacked soil is often used under laboratory conditions to describe burrowing behaviour of individual earthworm species, or to describe interspecific interactions between earthworm species (Joschko et al., 1991; Jégou et al., 1998; 
Version définitive du manuscrit publiée dans / Final version of the manuscript published in:

Geoderma (2012), Vol. 202, p. 45-50, DOI: 10.1016/j.geoderma.2013.03.011

Journal homepage: www.elsevier.com/locate/geoderma

Jégou et al., 2001; Capowiez et al., 2001; Bastardie et al., 2003). X-ray tomography, as a nondestructive, accurate, and rapid method allows a global representation of the organisation of soil macroporosity (Capowiez et al., 2011). In repacked soil cores, 3-D reconstructions of burrow systems using X-ray tomography have been used to assess changes in the earthworm burrowing behaviour under several conditions, including metal pollution (Nahmani et al., 2005), pesticide exposure (Dittbrenner et al., 2011), or coal fly ash fertilisation (Yunusa et al., 2009).

The present study aims to determine the impact of lime addition in an acidified forest soil on the burrowing behaviour of earthworm, by using X-ray tomography. Lime addition is an increasingly used management practice in the Vosges Mountains (North-eastern, France) to counteract soil acidity and increase forest soil fertility (Landmann and Bonneau, 1995; Bonneau, 2005; van der Heijden et al., 2011). The objectives of this study include: 1) quantification of earthworm burrow structural features (mean diameter, burrow number, burrow distribution by soil depth) of the endogeic Aporrectodea caliginosa Savigny and the anecic A. giardi Ribaucourt species in limed and non-limed soils and 2) comparison of the burrowing and surface casting activities of these earthworms in recent (in vitro) versus prior (in situ) limed soils. We expect an increase of earthworm activities (burrowing and casting) by in vitro and in situ lime addition into the acidic forest soil. To this extent, we used cores with repacked soil sampled in the Vosges Mountains under laboratory conditions.

\section{Material and Methods}

\subsection{Soils and earthworms}


Version définitive du manuscrit publiée dans / Final version of the manuscript published in:

Geoderma (2012), Vol. 202, p. 45-50, DOI: 10.1016/j.geoderma.2013.03.011

Journal homepage: www.elsevier.com/locate/geoderma

Soils used in this study were collected from two granitic forest catchments dominated by beech (Fagus sylvatica) located in the Vosges Mountains (North-eastern, France): a nonlimed control catchment $\left(47^{\circ} 57^{\prime} 39.5^{\prime \prime} \mathrm{N}-006^{\circ} 53^{\prime} 05.1^{\prime \prime} \mathrm{E}\right.$; Altitude: $\left.1060 \mathrm{~m}\right)$, and an adjacent, limed catchment $\left(47^{\circ} 57^{\prime} 22.9^{\prime \prime} \mathrm{N}-006^{\circ} 52^{\prime} 55.6^{\prime \prime} \mathrm{E}\right.$, Altitude: $\left.1045 \mathrm{~m}\right)$. The calcareous amendment (dolomite) was spread by helicopter in October 2003 (i.e. 6 years before the laboratory study) as a fine powder composed of $70 \% \mathrm{CaCO}_{3}, 17 \% \mathrm{MgCO}_{3}, 10 \%$ $\mathrm{CaSO}_{4}$ and $3 \% \mathrm{KCl}$ at $2.5 \mathrm{tha}^{-1}$.

Catchment soils are Entic Podzols according to WRB Classification (2006). Soil texture in the upper $30 \mathrm{~cm}$ of the non-limed catchment was $55.8 \%$ sand, $22.4 \%$ silt, and $21.8 \%$ clay. It contained $29.3 \%$ organic matter and had WHC of $0.16 \mathrm{~g} \mathrm{~g}^{-1}$. The mean $\mathrm{pH}$ (measured in water) of the $\mathrm{OH}$ horizon was 3.8, and the A horizon was 4.5. Soil texture in the upper $30 \mathrm{~cm}$ of the limed catchment was $58.7 \%$ sand, $22.9 \%$ silt, $18.4 \%$ clay. It contained $23.3 \%$ organic matter and had WHC of $0.18 \mathrm{~g} \mathrm{~g}^{-1}$. Mean $\mathrm{pH}$ in this treated catchment was 4.1 in the $\mathrm{OH}$ horizon and 4.7 in the A horizon.

The $\mathrm{OH}$ and A horizons of non-limed and limed catchments were sampled. Soils for the nonlimed control came from the non-limed catchment, and soils for the in situ limed treatment came from the limed catchment. After field collections, $\mathrm{OH}$ and A horizons were sieved through $3.9 \mathrm{~mm}$ mesh and stored at $12^{\circ} \mathrm{C}$ for one week before repacking for the experiment.

The two earthworm species studied belong to two different ecological categories: $A$. giardi is anecic and A. caliginosa is endogeic. Adult earthworms were collected by handsorting from an experimental plot in La Bouzule (48 $74^{\prime} 10.3^{\prime \prime} \mathrm{N}-006^{\circ} 32^{\prime} 59^{\prime}$ 'E). For acclimation, earthworms were stored at $12^{\circ} \mathrm{C}$ for one week with $200 \mathrm{~g}$ of beech litter and $5 \mathrm{~kg}$ of non-limed $\mathrm{OH}$ and A horizon soil prior the start of the experiment. 
Version définitive du manuscrit publiée dans / Final version of the manuscript published in:

Geoderma (2012), Vol. 202, p. 45-50, DOI: 10.1016/j.geoderma.2013.03.011

Journal homepage: www.elsevier.com/locate/geoderma

\subsection{Experimental procedure}

The experiment was performed using PVC cylinders $(15.5 \mathrm{~cm}$ diameter, $30 \mathrm{~cm}$ long) with a $1 \mathrm{~mm}$ nylon mesh at the bottom to allow the passage of gas and water. Three soil treatments (i.e. non-limed, in situ and in vitro limed) were established by filling the PVC cylinders with $20 \mathrm{~cm}$ of sieved A horizon soil, to which $5 \mathrm{~cm}$ of sieved $\mathrm{OH}$ horizon soil was added (Table 1a). For the in vitro limed soil treatment, we used $\mathrm{OH}$ horizon soil collected from the non-limed catchment into which we mixed $5 \mathrm{~g}$ of lime (mean $\mathrm{pH}=5.4$ ), which is equivalent to the 2003 catchment-level application of $2.5 \mathrm{t} \mathrm{ha}^{-1}$. We placed this freshly limed soil above sieved A horizon soil (mean $\mathrm{pH}=4.5$ ) from the non-limed catchment.

Field soil bulk density $\left(0.8 \mathrm{~g} \mathrm{~cm}^{-3}\right)$ was achieved by repacking the soil and pressing it for 5 minutes with a hydraulic press at 0.75 bar. Seven layers of $0.7 \mathrm{~kg}$ each were sequentially added to reproduce the A horizon. Two layers of $0.4 \mathrm{~kg}$ each were added and packed to reproduce the $\mathrm{OH}$ horizon. Soil cores were acclimated in a climate chamber at $12^{\circ} \mathrm{C} \pm 1{ }^{\circ} \mathrm{C}$ for two days before earthworm inoculation.

Each core of three replicates per treatment was inoculated with either two individuals of $A$. giardi or two individuals of A. caliginosa (Table 1b). In total, 36 earthworms were applied. Individual A. giardi earthworms initially weighed $2.56 \pm 0.3 \mathrm{~g}$ (mean $\pm \mathrm{SD}$, fresh weight) and A. caliginosa individuals weighed $0.73 \pm 0.1 \mathrm{~g}$. We prepared one earthworm-free control core for each soil treatment. To each core, after inoculation with earthworms, we added $5 \mathrm{~g}$ (fresh mass) of beech leaves - sampled from the litter layer of the non-limed and limed catchments -as a food source. We also added $150 \mathrm{~mL}$ of distilled water in each core to remoisten the soil and the litter during the experiment. All cores were kept in a climate 
Version définitive du manuscrit publiée dans / Final version of the manuscript published in:

Geoderma (2012), Vol. 202, p. 45-50, DOI: 10.1016/j.geoderma.2013.03.011

Journal homepage: www.elsevier.com/locate/geoderma

chamber at $12^{\circ} \mathrm{C} \pm 1{ }^{\circ} \mathrm{C}$ with a light/dark cycle of $16 / 8$ h for 9 weeks from November 2009 to January 2010.

\subsection{3-D reconstruction of the burrow system and topology analysis}

After the 9 weeks incubation, each column was scanned at the INRA Nancy Centre using a medical X-ray tomograph (General Electrics; brightspeed exel) according to the method described in Capowiez et al. (1998). Columns were scanned horizontally at $130 \mathrm{kV}$ and $80 \mathrm{~mA} \mathrm{~s}^{-1}$, providing 2-D images $(1.25 \mathrm{~mm}$ thick every $1.25 \mathrm{~mm})$ of the soil macroporosity. After a simple binarization of the 2-D images presenting two well separated peaks in the grey level histogram, the 3-D volume reconstruction was run by a specific algorithm (Pierret et al., 2002). The 3-D skeletons were also reconstructed by connecting the centroids of pores that overlapped between two successive images (Capowiez et al., 1998). Density parameters were analysed to obtain several characteristics: number of burrows, total burrow length, and total burrow volume. In order to evaluate the earthworm activity throughout the soil core, the cumulative burrow volume $\left(\mathrm{cm}^{3}\right)$ was summed to $25 \mathrm{~cm}$ depth. We use the slope of cumulative volume by depth relationship (expressed in $\mathrm{cm}^{3} \mathrm{~cm}^{-1}$ ) as a measure of earthworm activity.

\subsection{Surface earthworm casts, soil core $\mathrm{pH}$ and earthworm biomass}

After column scanning, earthworm cast production (CP, expressed as mg of dry casts $\mathrm{g}^{-1}$ of fresh earthworm initial weight $\mathrm{d}^{-1}$ ) was measured by collecting surface casts drying at $60^{\circ} \mathrm{C}$ for 3 days, and weighing. Afterward, each column was destructively harvested by layer and earthworms were hand-sorted. Earthworm survival was assessed by gently prodding 
Version définitive du manuscrit publiée dans / Final version of the manuscript published in:

Geoderma (2012), Vol. 202, p. 45-50, DOI: 10.1016/j.geoderma.2013.03.011

Journal homepage: www.elsevier.com/locate/geoderma

individuals using a Pasteur pipet. Earthworms were then rinsed with distilled water, gently dried with filter paper and weighed. Soil $\mathrm{pH}$ was measured by soil horizon at the end of the experiment using a 1:5 soil:water ratio.

\subsection{Statistical analysis}

Student t-tests or Welch tests (when the homogeneity of variance was not verified) were used to assess effects of soil and earthworm treatments on each burrow system characteristic, cast production, slope of the cumulative burrow-depth relationship, and final $\mathrm{pH}$. Paired t-tests assessed the difference between initial and final $\mathrm{pH}$ for each individual depth of soil and earthworm treatment. All analyses were conducted using $\mathrm{R}$ software ( $\mathrm{R}$ Development Core Team, 2008).

\section{Results}

\subsection{Soil core pH}

At the beginning of the experiment (T0), after lime addition into the upper $5 \mathrm{~cm}$ of the in vitro limed soils ( $\mathrm{OH}$ horizon), $\mathrm{pH}$ was 5.4 and was significantly greater than for the other soil treatments $(\mathrm{P}<0.01$; Table 2$)$. The $\mathrm{pH}$ of the upper $5 \mathrm{~cm}$ soil of the in situ limed treatment was also significantly greater than in the non-limed treatment $(\mathrm{P}=0.03$; Table 2$)$. These differences remained at the end of experiment (Tf) for each earthworm treatment $(\mathrm{P}<$ 0.01) and in control incubations (Table 2). In the A layer at $\mathrm{T} 0$, the $\mathrm{pH}$ of the in situ limed treatment was significantly greater than in the two other treatments $(\mathrm{P}<0.01)$. The final $(\mathrm{Tf})$ $\mathrm{pH}$ in the A layer of the A. giardi treatment was similar to T0 $(\mathrm{P}=0.19)$ and $\mathrm{Tf}$ values were similar across soil treatments $(\mathrm{P}=0.10)$. For the A. caliginosa treatment, the final A layer $\mathrm{pH}$ 
Version définitive du manuscrit publiée dans / Final version of the manuscript published in:

Geoderma (2012), Vol. 202, p. 45-50, DOI: 10.1016/j.geoderma.2013.03.011

Journal homepage: www.elsevier.com/locate/geoderma

in the in situ limed treatment was significantly smaller than at the start of incubation $(\mathrm{P}=$ 0.02), but $\mathrm{pH}$ increased in the in vitro limed treatment during the experiment $(\mathrm{P}=0.04)$.

\subsection{Final earthworm biomass and surface cast production}

All earthworms were alive at the end of experiment, as indicated by physical reactions to Pasteur pipet stimulation. Biomass of both species decreased during the experiment for each soil treatment (Table 3). A. giardi lost significantly more weight in the non-limed treatment than in either limed treatment $(\mathrm{P}=0.02$ for non-limed vs. in situ limed and $\mathrm{P}=0.01$ for non-limed vs. in vitro limed treatment). They lost $59.2 \%$ of initial biomass in the nonlimed soil and 13.7 to $23.2 \%$ in the limed treatments. For A. caliginosa the mass loss was not significantly different between the soil treatments and ranged from $12.2 \%$ to $22.3 \%$ (Table $3)$.

Cast production (CP) by A. giardi in the in vitro limed treatment was significantly higher than in the non-limed treatment $(\mathrm{P}<0.01)$ but not different from the in situ limed treatment $(\mathrm{P}=0.30$; Table 3). Surprisingly, the endogeic worm A. caliginosa seemed to produce more surface casts than A. giardi. Anyway, no significant differences were found for A. caliginosa cast production between soil treatments and its production ranged from 63.6 to $109.6 \mathrm{mg} \mathrm{g}^{-1} \mathrm{~d}^{-1}$ (Table 3).

\subsection{Burrowing patterns}

\subsubsection{3-D burrow system characteristics}

Burrow networks occupied the entire column depth for all earthworm treatment (Fig. 1). A. giardi built large-volume, vertically oriented burrows, while A. caliginosa burrow 
Version définitive du manuscrit publiée dans / Final version of the manuscript published in:

Geoderma (2012), Vol. 202, p. 45-50, DOI: 10.1016/j.geoderma.2013.03.011

Journal homepage: www.elsevier.com/locate/geoderma

volumes were smaller and more horizontal. A. giardi burrowed a significantly higher total volume in the in vitro limed treatment than in the non-limed treatment $(\mathrm{P}<0.01$; Table 4$)$, whereas the volume burrowed in the in situ treatment was not significantly different from the non-limed treatment. The same pattern was observed for the total burrow length $(\mathrm{P}=0.01)$. No significant liming effect was found for the total burrow length or volume burrowed by $A$. caliginosa (P > 0.05; Table 4). Moreover, A. giardi burrowed a significantly higher volume in the in vitro limed treatment than $A$. caliginosa (Table 4; $\mathrm{P}<0.01$ ). However, A. caliginosa excavated 2 to 3 times longer $\left(\mathrm{m} \mathrm{g}^{-1}\right.$ of initial earthworm biomass; $\left.\mathrm{P}<0.05\right)$ and 2 to 5 times more burrows $(\mathrm{P}<0.04)$ than $A$. giardi. Finally, the mean burrow length dug in the $\mathrm{OH}$ horizon (top $5 \mathrm{~cm}$ ) was higher in the in vitro limed treatment than in either other soils for both species (Table 4; Fig.1).

\subsubsection{Mean cumulative volume of burrows as a function of depth}

The mean cumulative burrow volume versus depth relationship differed by soil treatment and species (Fig. 2). In the in situ limed and non-limed treatment, burrow volume increased linearly as a function of core depth regardless of species. In the in vitro limed treatment, this relationship showed two phases: first, a rapid and linear increase of burrow volume in the $0-5 \mathrm{~cm}$ layer $(\mathrm{OH}$ horizon), and second, a linear but slower excavated volume increase for 5-20 cm depth (A horizon). The relationship was significantly different between the in vitro limed and non-limed soil treatments for $A$. giardi in the $\mathrm{OH}$ horizon $(\mathrm{P}=0.02)$, with the mean slope of 0.28 for non-limed, 0.17 for in situ limed, and $0.06 \mathrm{~cm}^{3} \mathrm{~cm}^{-1}$ for in vitro limed soils. For $A$. caliginosa, the same difference was denoted $(\mathrm{P}=0.04$; mean slope: $0.61 ; 0.33$ and $0.17 \mathrm{~cm}^{3} \mathrm{~cm}^{-1}$ in the non-limed, in situ and in vitro limed treatments, respectively). In the A horizon, no significant difference was found for either species across 
Version définitive du manuscrit publiée dans / Final version of the manuscript published in:

Geoderma (2012), Vol. 202, p. 45-50, DOI: 10.1016/j.geoderma.2013.03.011

Journal homepage: www.elsevier.com/locate/geoderma

treatments $\left(0.43 ; 0.30 ; 0.42\right.$ and $0.53 ; 0.66 ; 0.68 \mathrm{~cm}^{3} \mathrm{~cm}^{-1}$ in the non-limed, in situ and in vitro limed treatments for A. giardi, A. caliginosa, respectively). In the $\mathrm{OH}$ horizon, the slope was significantly smaller for A. giardi than A. caliginosa in the in vitro limed treatment $(\mathrm{P}<$ $0.01)$.

\section{Discussion}

As expected, adding lime in the laboratory to acidified forest soils collected from the Vosges Mountains increased soil $\mathrm{pH}$ of the $\mathrm{OH}$ horizon from 4.0 to 5.4. During the 9 weeks of experiment, the lime mixed into the surface horizon affected deeper soil $\mathrm{pH}$, especially in the presence of the endogeic earthworm A. caliginosa. Chan et al. (2004) found that $A$. caliginosa, A. longa, and A. trapezoides incorporated surface applied lime after 18 months in an acidic Australian pasture soil. Ingestion and deposition of casts below ground or by adherence on earthworm bodies transported the lime and incorporated it into deeper layers. In our laboratory experiment, we mixed the dolomite into the $\mathrm{OH}$ horizon to immediately assess its effect on the burrowing behaviour of earthworms. In the forest, dolomite is usually applied at the soil surface without any mixing. However, we expect that it leaches after dissolution and/or is incorporated by endogeic and anecic earthworm activities in deeper soil layers, inducing an increase of soil $\mathrm{pH}$ and of nutrient availability.

All earthworms of each species used in our experiment survived in the acidic soil for 9 weeks. As such, soil acidity at $\mathrm{pH}$ values as low as 3.8 were not lethal during this experiment. However, in the suboptimal experimental conditions, all individuals lost weight with A. giardi losing more weight than A. caliginosa. Experimental conditions recommended by Fründ et al (2010) were carefully followed in our study. They suggest that control earthworm weight loss 
Version définitive du manuscrit publiée dans / Final version of the manuscript published in:

Geoderma (2012), Vol. 202, p. 45-50, DOI: 10.1016/j.geoderma.2013.03.011

Journal homepage: www.elsevier.com/locate/geoderma

should be less than $30 \%$ during long-term experiments if we are to draw valid conclusions from the experimental results. For both studied species, the inoculated earthworms lost between 12 and $23 \%$ except for the A. giardi which lost $59 \%$ of body mass in the non-limed soil. Thus, without the lime, soil $\mathrm{pH}$ will likely limit $A$. giardi activity.

Räty (2004) described A. caliginosa as a eurytopic species inhabiting a variety of habitats. Sparse populations of this species have been found at pH 3.6 (Bouché, 1972). This acid-tolerant species was also found in or introduced to and survived in soils with $\mathrm{pH}$ values from 3.9 to 7.0 (Robinson et al., 1996; Chan et al., 2004; Räty and Huhta, 2003 and 2004; Potthoff et al., 2008). A. giardi has been described as neutrophilic but tolerant to acidity and can live in soil with low organic matter (Bouché, 1972). In a laboratory study, Salmon and Ponge (1999) successfully introduced this species in a forest eumoder, in an oligomull and in a calcic eumull with soil $\mathrm{pH}$ ranging from 4.0 to 7.4. In our study, A. giardi appeared sensitive to a small $\mathrm{pH}$ change and lime addition was likely to improve the habitat conditions since the species lost less biomass in limed soil. This biomass loss may also be explained by the low food quality of beech leaves (protein, carbohydrates, lignin content; Curry and Schmidt, 2007). This concept is also highlighted by Vahder and Irmler (2012) in two German forests where beech dominance was negatively correlated with the soil $\mathrm{pH}$ and endogeic earthworm biomass. The authors suggest that this pattern may be explained by the low quality and digestibility of beech litter.

The observed burrowing activity of A. caliginosa was typical for endogeic species: narrow, horizontal and long burrows (Jégou et al., 1998, 2001; Langmaack et al., 1999; Bastardie et al., 2002; Dittbrenner et al., 2011). In the non-limed and in situ limed soils, this species did not show any depth preference as the burrows were found at every depths of the core. This contrasts with Jégou et al. (1998) who found A. caliginosa burrowed to a maximum 
Version définitive du manuscrit publiée dans / Final version of the manuscript published in:

Geoderma (2012), Vol. 202, p. 45-50, DOI: 10.1016/j.geoderma.2013.03.011

Journal homepage: www.elsevier.com/locate/geoderma

depth of $13 \mathrm{~cm}$ but most activity was in the top $7-8 \mathrm{~cm}$ in a laboratory incubation with repacked cultivated soil from Brittany, France kept for 246 days. McKenzie and Dexter (1993) observed that the most complex region of the burrow network of A. caliginosa was located between 2.5 and $5 \mathrm{~cm}$. Others have found A. caliginosa active in both the topsoil and subsoil (Joschko et al., 1991; Pitkänen and Nuutinen, 1997; Francis and Fraser, 1998; Langmaack et al., 1999). This shows that the burrowing behaviour of A. caliginosa is extremely dependent on soil characteristics and highlights the need for further earthworm burrow characterization. Furthermore, our study demonstrated that A. caliginosa had a depth preference for the topsoil $(0-5 \mathrm{~cm})$ after in vitro lime addition, which increased the $\mathrm{pH}$ in that depth from 4.0 to near 5.5.

In vitro liming stimulated $A$. giardi burrowing as evidenced by increased surface casting and increased soil excavation. These increases were most prominent in the top $5 \mathrm{~cm}$. The burrow system produced by the anecic $A$. giardi was characterised by approximately 20 burrows; and thus differed from the single, permanent, nearly vertical channels described for the well-studied epi-anecic Lumbricus terrestris, (Jégou et al., 1998; Shipitalo and Le Bayon, 2004; Bastardie et al., 2005). In their 246 day incubation of a cultivated soil from the deep mineral horizon, Jégou et al. (1998) found that the burrow system excavated by two individuals of $A$. giardi often reached the bottom of the column and maximal activity occurred between 4 and $23 \mathrm{~cm}$. In our study, A. giardi did not show any depth preference in the nonlimed and in situ soil treatments, but it had increased activity and excavated longer burrows after in vitro liming, which induced the soil $\mathrm{pH}$ increase from 4.0 to near 5.5.

When comparing the burrow system of the two species regardless of soil $\mathrm{pH}, A$. caliginosa burrows were at least twice the length of burrows by A. giardi when standardized by biomass. This contrasts markedly with the 246 day laboratory incubation by Jégou et al. (2001), who found in a cultivated soil, that A. caliginosa burrows were four times shorter than 
Version définitive du manuscrit publiée dans / Final version of the manuscript published in:

Geoderma (2012), Vol. 202, p. 45-50, DOI: 10.1016/j.geoderma.2013.03.011

Journal homepage: www.elsevier.com/locate/geoderma

in our study, and that $A$. giardi burrowed approximately the same length as in our study, and thus more than A. caliginosa. This may be due to differing soil nature and soil bulk density: $1.35 \mathrm{~g} \mathrm{~cm}^{-3}$ in their study versus $0.8 \mathrm{~g} \mathrm{~cm}^{-3}$ in our study. Perhaps, the worms were also searching more for food or favorable conditions (Jégou et al., 1999).

Finally, for both species, the volume, length, and number of burrows did not differ between in situ limed and non-limed soil. The burrow systems were similar even though $A$. giardi lost less biomass and produced more casts in the in situ limed treatment than in the non-limed soil. Thus, six years after field liming, the management practice did not improve the burrowing activities of either of the earthworm species studied here. This may be explained by the remaining acidic conditions of the in situ limed soil, which is consistent with another laboratory study that investigated the impact of liming on the casting activity of Lumbricus terrestris in soils of the same stand as the present paper (Auclerc et al., 2011). Our previous work showed that the liming needed to increase soil $\mathrm{pH}$ to 5.3 under laboratory conditions in order to enhance earthworm activity, which is greater than the non- and in situlimed soils of the present study.

\section{Conclusion}

The use of X-ray computed tomography provides insights into understanding of the impacts of liming (a restoration method used in declined forests) on the burrowing activities of earthworm species which function as soil engineers. Liming affected the burrowing activity of the anecic A. giardi more than the endogeic A. caliginosa after a short term limed application (in vitro limed soil). In contrast, liming in the field six years prior to experiment 
Version définitive du manuscrit publiée dans / Final version of the manuscript published in:

Geoderma (2012), Vol. 202, p. 45-50, DOI: 10.1016/j.geoderma.2013.03.011

Journal homepage: www.elsevier.com/locate/geoderma

(in situ limed soil) did not positively effect earthworm activity. Owing to the importance of earthworm burrows for ecosystem functioning, their 3-D reconstruction by X-ray tomography is a useful tool for assessing and describing the effects of driving variables on earthworm activity across ecosystems.

\section{Acknowledgments}

This project was carried out with financial support from the National Research Agency (ANR) and Zone Atelier Moselle (ZAM). We thank Charline Freyburger from the National Institute of Agronomic Research (INRA) of Nancy, for her help with the tomography study and the technical staff of INRA of Avignon for their help in column construction. We are also grateful to J. M. Crumsey, K. J. Nadelhoffer and J. M. LeMoine for the English-language editing.

\section{References}

Auclerc, A., Nahmani, J., Huguier, P., Capowiez, Y., Aran, D., Guérold, F., 2011. Adapting ecotoxicological tests based on earthworm behavior to assess the potential effectiveness of forest soil liming. Pedobiologia, 54S, S63-S68.

Bastardie, F., Cannavacciuolo, M., Capowiez, Y., de Dreuzy, J.-R., Bellido, A., Cluzeau, D., 2002. A new simulation for modelling the topology of earthworm burrow systems and their effects on macropore flow in experimental soils. Biol. Fertil. Soils 36, 161-169.

Bastardie, F., Capowiez, Y., de Dreuzy, J.-R., Cluzeau, D., 2003. X-ray tomographic and hydraulic characterization of burrowing by three earthworm species in repacked soil cores. Appl. Soil Ecol. 24, $3-16$.

Bastardie, F., Capowiez, Y., Cluzeau, D., 2005. 3D characterisation of earthworm burrow systems in natural soil cores collected from a 12-year-old pasture. Appl. Soil Ecol. 30, 34-46.

Bonneau, M., 2005. Evolution of the mineral fertility of an acidic soil during a period of ten years in the Vosges Mountains (France). Impact of humus mineralisation. Ann. For. Sci. 62, 253-260.

Bouché, M.B., 1972. Lombriciens de France: Ecologie et Systématique, Institut National de la Recherche Agronomique, Paris, 1972. 
Version définitive du manuscrit publiée dans / Final version of the manuscript published in:

Geoderma (2012), Vol. 202, p. 45-50, DOI: 10.1016/j.geoderma.2013.03.011

Journal homepage: www.elsevier.com/locate/geoderma

Campbell, G., Lee, D., 1996. Atmospheric deposition of sulphur and nitrogen species in the U.K. Freshw. Biol. 36, 151-167.

Capowiez, Y., Pierret, A., Daniel, O., Monestiez, P., Kretzschmar, A., 1998. 3D skeleton reconstructions of natural earthworm burrow systems using CAT scan images of soil cores. Biol. Fertil. Soils 27, 51-59.

Capowiez, Y., Monestiez, P., Belzunces, L., 2001. Burrow systems made by Aporrectodea nocturna and Allolobophora chlorotica in artificial cores: morphological differences and effects of interspecific interactions. Appl. Soil Ecol. 16, 109-120.

Capowiez, Y., Sammartino, S., Michel, E., 2011. Using X-ray tomography to quantify earthworm bioturbation non-destructively in repacked soil cores. Geoderma, 162, 124-131.

Chan, K. Y., Baker, G. H., Conyers, M.K., Scott, B., Munro, K., 2004. Complementary ability of three European earthworms (Lumbricidae) to bury lime and increase pasture production in acidic soils of south-eastern Australia. Appl. Soil Ecol. 26, 257-271.

Curry, J. P., Schmidt, O., 2007. The feeding ecology of earthworms - A review. Pedobiologia 50, 463477.

Deleporte, S., Tillier, P., 1999. Long-term effects of mineral amendments on soil fauna and humus in an acid beech forest floor. Forest Ecol. Manag. 118, 245-252.

Dittbrenner, N., Moser, I., Triebskorn, R., Capowiez, Y., 2011. Assessment of short and long-term effects of imidacloprid on the burrowing behaviour of two earthworm species (Aporrectodea caliginosa and Lumbricus terrestris) by using 2D and 3D post-exposure techniques. Chemosphere 84, $1349-1355$.

Driscoll, C.T., Lawrence, G.B., Bulger, A.J., Butler, T.J., Cronan, C., S., Eagar, C., Lambert, K.F., Likens, G.E., Stoddard, J.L., Weathers, K.C., 2001. Acidic deposition in the Northeastern United States: sources and inputs, ecosystem effects, and management strategies. BioSci. 51, 180-198.

Edwards, C.A., Bohlen, P.J., 1996. Biology and Ecology of Earthworms. Chapman and Hall, London.

Francis, G.S., Fraser, P. M., 1998. The effects of three earthworm species on soil macroporosity and hydraulic conductivity. Appl. Soil Ecol. 10, 11-19.

Fründ, H.-C., Butt, K., Capowiez, Y., Eisenhauer, N., Emmerling, C., Ernst, G., Potthoff, M., Schädler, M., Schrader, S., 2010. Using earthworms as model organisms in the laboratory: Recommendations for experimental implementations. Pedobiologia 53, 119-125.

Formanek, P., Vranova, V., 2002. A contribution to the effect of liming on forest soils: review of literature. J. For. Sci. 48, 182-190.

Godbold, D.L., 2003. Managing Acidification and Acidity in Forest Soils, In: Rengel. Z. (Ed.), Handbook of Soil Acidity. Dekker, M., New York, pp. 438-455.

Graefe, U., Beylich, A., 2003. Critical values of soil acidification for annelid species and the decomposer community, in: Didden, W., van Vliet, P. (Eds.), Proceedings of the 5th International Symposium on Enchytraeidae, Newsletter on Enchytraeidae 8. Wageningen University, Department of Soil Quality, pp. 51-55.

Hüttl, R. F., Zöttl, H. W., 1993. Liming as a mitigation tool in Germany's declining forests-reviewing results from former and recent trials. Forest Ecol. Manag. 61, 325-338. 
Version définitive du manuscrit publiée dans / Final version of the manuscript published in:

Geoderma (2012), Vol. 202, p. 45-50, DOI: 10.1016/j.geoderma.2013.03.011

Journal homepage: www.elsevier.com/locate/geoderma

Jégou, D., Cluzeau, D., Wolf, H.J., Gandon, Y., Tréhen, P., 1998. Assessment of the burrow system of Lumbricus terrestris, Aporrectodea giardi, and Aporrectodea caliginosa using X-ray computed tomography. Biol. Fertil. Soils 26, 116-121.

Jégou, D., Hallaire, V., Cluzeau, D., Tréhen, P., 1999. Characterization of the burrow system of the earthworms Lumbricus terrestris and Aporrectodea giardi using X-ray computed tomography and image analysis. Biol. Fertil. Soils 29, 314-318.

Jégou, D., Capowiez, Y., Cluzeau, D., 2001. Interactions between earthworm species in artificial soil cores assessed through the 3D reconstruction of the burrow systems. Geoderma, 102, 123-137.

Jones, C.G., Lawton, J.H., Schachak, M., 1994. Organisms as ecosystem engineers. Oikos 69, 373386.

Joschko, M., Graff, O., Müller, P.C., Kotzke, K., Lindner, P., Pretschner, D.P., Larink, O., 1991. A non-destructive method for the morphological assessment of earthworm burrow systems in three dimensions by X-ray computed tomography. Biol. Fertil. Soils 11, 88-92.

Judas, M., Schauermann, J., Meiwes, K.-J., 1997. The inoculation of Lumbricus terrestris L. in an acidic spruce forest after liming and its influence on soil properties. Soil Biol. Biochem. 29, 677-679.

Kreutzer, K., 1995. Effects of forest liming on soil processes. Plant Soil 168-169, 447-470.

Landmann, G., Bonneau, M., 1995. Forest Decline and Atmospheric Deposition Effects in the French Mountains. Springer Verlag, Berlin, pp. 461.

Langmaack, M., Schrader, S., Rapp-Bernhardt, U., Kotzke, K., 1999. Quantitative analysis of earthworm burrow systems with respect to biological soil-structure regeneration after soil compaction. Biol. Fertil. Soils 28, 219-229.

Lavelle, P., Decaëns, T., Aubert, M., Barot, S., Blouin, M., Bureau, F., Margerie, P., Mora., P., Rossi, J.-P., 2006. Soil invertebrates and ecosystem services. Eur. J. Soil Biol., 42: S3-S15.

McKenzie, B.M., Dexter, A.R., 1993. Size and orientation of burrows made by the earthworms Aporrectodea rosea and A. caliginosa. Geoderma 56, 233-241.

Nahmani, J., Capowiez, Y., Lavelle, P., 2005. Effects of metal pollution on soil macroinvertebrate burrow systems. Biol. Fertil. Soils 42, 31-39.

Pierret, A., Capowiez, Y., Belzunces, L., Moran, C. J., 2002. 3D reconstruction and quantification of macropores using X-ray computed tomography and image analysis. Geoderma 106, 247-271.

Pitkänen, J., Nuutinen, V., 1997. Distribution and abundance of burrows formed by Lumbricus terrestris L. and Aporrectodea caliginosa Sav. in the soil profile. Soil Biol. Biochem. 29, 463-467.

Potthoff, M., Asche, N., Stein, B., Muhs, A., Beese, F., 2008. Earthworm communities in temperate beech wood forest soils affected by liming. Eur. J. Soil Biol. 44, 247-254.

Räty, M., 2004. Growth of Lumbricus terrestris and Aporrectodea caliginosa in an acid forest soil, and their effects on enchytraeid populations and soil properties. Pedobiologia 48, 321-328.

Räty, M., Huhta, V., 2003. Earthworms and pH affect communities of nematodes and enchytraeids in forest soil. Biol. Fertil. Soils 38, 52-58. 
Version définitive du manuscrit publiée dans / Final version of the manuscript published in:

Geoderma (2012), Vol. 202, p. 45-50, DOI: 10.1016/j.geoderma.2013.03.011

Journal homepage: www.elsevier.com/locate/geoderma

Räty, M., Huhta, V., 2004. Earthworm communities in birch stands with different origin in central Finland. Pedobiologia 48, 283-291.

R Development Core Team, 2008. R: A Language and Environment for Statistical Computing. R Foundation for Statistical Computing, Vienna, Austria. ISBN 3-900051-07-0, http://www.Rproject.org.

Robinson, C. H., Piearce, T. G., Ineson, P., 1991. Burrowing and soil consumption by earthworms in limed and unlimed soils from Picea Sitchensis plantations Pedobiologia 35, 360-367

Robinson, C. H., Ineson, P., Piearce, T. G., Parrington, J., 1996. Effects of earthworms on cation and phosphate mobilisation in limed peat soils under Picea sitchensis. Forest Ecol. Manag. 86, 253-258.

Salmon, S., Ponge, J-F., 1999. Distribution of Heteromurus nitidus (Hexapoda, Collembola) according to soil acidity: interactions with earthworms and predator pressure. Soil Biol. Biochem. 31, 11611170 .

Shipitalo, M.J., Le Bayon, R.C., 2004. Quantifying the effects of earthworms on soil aggregation and porosity. In: Edwards, C.A. (Ed.) Earthworm ecology. 2nd ed. CRC Press, Boca Raton, FL., pp. 183200.

Springett, J. A, Syers, J.K., 1984. Effect of $\mathrm{pH}$ and calcium content of soil on earthworm cast production in the laboratory. Soil Biol. Biochem. 16, 185-189.

Theenhaus, A., Schaefer, M., 1995. The effects of clear-cutting and liming on the soil macrofauna of a beech forest. Forest Ecol. Manag. 77, 35-51.

Vahder, S., Irmler, U., 2012. Effect of pure and multi-species beech (Fagus sylvatica) stands on soil characteristics and earthworms in two northern German forests. Eur. J. Soil Biol. 51, 45-50.

van der Heijden, G., Legou, A., Nicolas, M., Ulrich, E., Johnson, D. W., Dambrine E., 2011. Longterm sustainability of forest ecosystems on sandstone in the Vosges Mountains (France) facing atmospheric deposition and silvicultural change. Forest Ecol. Manag. 261, 730-740.

WRB Classification, 2006. World Reference Base for Soil Resources 2006, 2nd Edition. IUSS Working Group WRB, World Soil Resources Reports No. 103. FAO, Rome, pp. 128.

Yunusa, I.A.M., Braun, M., Lawrie, R., 2009. Amendment of soil with coal fly ash modified the burrowing habit of two earthworm species. Appl. Soil Ecol. 42, 63-68. 
Version définitive du manuscrit publiée dans / Final version of the manuscript published in:

Geoderma (2012), Vol. 202, p. 45-50, DOI: 10.1016/j.geoderma.2013.03.011

Journal homepage: www.elsevier.com/locate/geoderma

Figure captions

\section{Figure 1}

Reconstructions of 3-D burrows from X-ray computed tomography for representative incubations for each treatment. Color represents depth with blue burrows behind orange.

\section{Figure 2}

Mean cumulative burrow volume by soil depth for (a) Aporrectodea giardi and (b) Aporrectodea caliginosa. 
Fig. 1

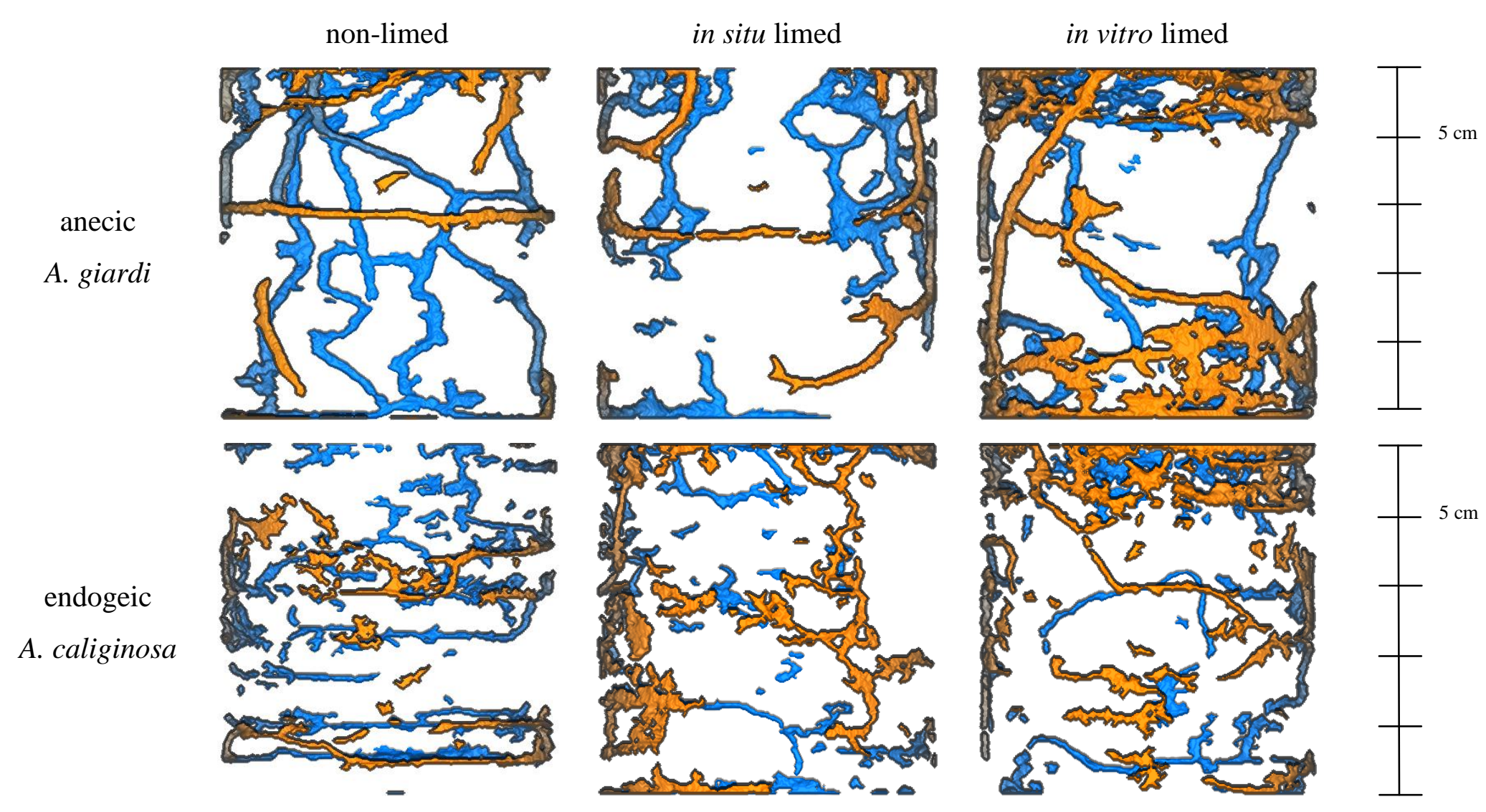




\section{Table 1}

Laboratory experiment soil source, lime addition, and earthworm treatments: (a) liming soil treatments by depth (b) total initial mass of two individual earthworms introduced to soil replicates by species.

\begin{tabular}{lll} 
Soil treatments & Soil in 0-5 cm & Soil in 5-25 cm \\
\hline non-limed & non-limed OH horizon & non-limed A horizon \\
in situ limed & in situ limed OH horizon & in situ limed A horizon \\
in vitro limed & non-limed OH horizon $+5 \mathrm{~g}$ lime & non-limed A horizon \\
\hline
\end{tabular}

(b)

\begin{tabular}{lll}
\hline $\begin{array}{l}\text { Earthworm } \\
\text { treatments }\end{array}$ & Species & $\begin{array}{l}\text { Total biomass inoculated (Mean (SD) } \\
\text { initial fresh weight, g) }\end{array}$ \\
\hline Anecic & Aporrectodea giardi (2 individuals) & $5.27(0.61)$ \\
Endogeic & Aporrectodea caliginosa (2 individuals) & $1.52(0.20)$ \\
\hline
\end{tabular}


Version définitive du manuscrit publiee dans / Final version of the manuscript published in:

Geoderma (2012), Vol. 202, p. 45-50, DOI: 10.1016/j.geoderma.2013.03.011

Journal homepage: www.elsevier.com/locate/geoderma

\section{Table 2}

Initial (T0) and final (Tf) soil pH by earthworm species treatment, soil liming treatment, and depth. Soil $\mathrm{pH}$ values are means (SD, $\mathrm{n}=3$ ) with 4 asterisks denoting significant differences between $\mathrm{T} 0$ and $\mathrm{Tf}$ (paired t-test) and letters denoting significant differences $(\mathrm{P}<0.05)$ for soil treatment 5 nested within earthworm treatment*time (t- or Welsh-tests).

\begin{tabular}{|c|c|c|c|c|c|c|c|c|c|c|c|c|}
\hline $\begin{array}{l}\text { Species } \\
\text { Treatments }\end{array}$ & \multicolumn{3}{|c|}{ T0 } & \multicolumn{3}{|c|}{$\begin{array}{c}\mathrm{Tf} \\
\text { Anecic A.giardi }\end{array}$} & \multicolumn{3}{|c|}{$\begin{array}{c}\mathrm{Tf} \\
\text { Endogeic A.caliginosa }\end{array}$} & \multicolumn{3}{|c|}{$\begin{array}{c}\mathrm{Tf} \\
\text { Control }\end{array}$} \\
\hline $\begin{array}{l}\text { Soil } \\
\text { Treatments }\end{array}$ & $\begin{array}{l}\text { non- } \\
\text { limed }\end{array}$ & $\begin{array}{l}\text { in situ } \\
\text { limed }\end{array}$ & $\begin{array}{l}\text { in vitro } \\
\text { limed }\end{array}$ & $\begin{array}{l}\text { non- } \\
\text { limed }\end{array}$ & $\begin{array}{l}\text { in situ } \\
\text { limed }\end{array}$ & $\begin{array}{l}\text { in vitro } \\
\text { limed }\end{array}$ & $\begin{array}{l}\text { non- } \\
\text { limed }\end{array}$ & $\begin{array}{l}\text { in situ } \\
\text { limed }\end{array}$ & $\begin{array}{l}\text { in vitro } \\
\text { limed }\end{array}$ & $\begin{array}{l}\text { non- } \\
\text { limed }\end{array}$ & $\begin{array}{l}\text { in situ } \\
\text { limed }\end{array}$ & $\begin{array}{l}\text { in vitro } \\
\text { limed }\end{array}$ \\
\hline OH horizon & $\begin{array}{c}3.8(0.02) \\
\mathrm{a}\end{array}$ & $\begin{array}{c}4.1(0.1) \\
b\end{array}$ & $\begin{array}{c}5.4(0.3) \\
\mathrm{c}\end{array}$ & $\begin{array}{c}4.1(0.1) \\
* \mathrm{~A}\end{array}$ & $\begin{array}{c}4.4(0.1) \\
\text { B }\end{array}$ & $\begin{array}{c}5.4(0.2) \\
C\end{array}$ & $\begin{array}{c}4.1(0.1) \\
* \mathrm{~A}\end{array}$ & $\begin{array}{c}4.3(0.1) \\
\mathrm{A}\end{array}$ & $\begin{array}{c}5.8(0.2) \\
\mathrm{B}\end{array}$ & 3.9 & 4.1 & 5.5 \\
\hline A horizon & $\begin{array}{c}4.5(0.02) \\
\mathrm{a}\end{array}$ & $\begin{array}{c}4.7(0.08) \\
b\end{array}$ & $\begin{array}{c}4.5(0.02) \\
\mathrm{a}\end{array}$ & $\begin{array}{c}4.7(0.2) \\
\mathrm{A}\end{array}$ & $\begin{array}{c}4.5(0.3) \\
\mathrm{A}\end{array}$ & $\begin{array}{c}4.7(0.1) \\
\mathrm{A}\end{array}$ & $\begin{array}{c}4.5(0.1) \\
\mathrm{AB}\end{array}$ & $\begin{array}{c}4.3(0.1) \\
* \mathrm{~A}\end{array}$ & $\begin{array}{c}4.8(0.1) \\
* \mathrm{~B}\end{array}$ & 4.3 & 4.3 & 4.7 \\
\hline
\end{tabular}

9

10 
Version définitive du manuscrit publiée dans / Final version of the manuscript published in:

Geoderma (2012), Vol. 202, p. 45-50, DOI: 10.1016/j.geoderma.2013.03.011

Journal homepage: www.elsevier.com/locate/geoderma

\section{Table 3}

19

20 Final earthworm biomass (\% of initial earthworm fresh biomass) and final surface casts ( $\mathrm{mg} \mathrm{g}^{-1}$ day $^{-1}$ ) by species and soil treatments. Masses are

21 means $(\mathrm{SD}, \mathrm{n}=3)$ with asterisk denoting significant difference $(\mathrm{P}<0.05)$ by species and letters denoting significantly $(\mathrm{P}<0.05)$ different soil 22 treatments within earthworm species (t- or Welsh-tests).

\begin{tabular}{|c|c|c|c|c|c|c|}
\hline \multirow{2}{*}{$\begin{array}{l}\text { Species } \\
\text { Treatment } \\
\text { Soil } \\
\text { Treatment }\end{array}$} & \multicolumn{3}{|c|}{$\begin{array}{c}\mathrm{Tf} \\
\text { Anecic A.giardi }\end{array}$} & \multicolumn{3}{|c|}{$\begin{array}{ll}\mathrm{Tf} \\
\text { Endogeic } & \text { A.caliginosa }\end{array}$} \\
\hline & $\begin{array}{l}\text { non- } \\
\text { limed }\end{array}$ & $\begin{array}{l}\text { in situ } \\
\text { limed }\end{array}$ & $\begin{array}{l}\text { in vitro } \\
\text { limed }\end{array}$ & $\begin{array}{l}\text { non- } \\
\text { limed }\end{array}$ & $\begin{array}{l}\text { in situ } \\
\text { limed }\end{array}$ & $\begin{array}{l}\text { in vitro } \\
\text { limed }\end{array}$ \\
\hline $\begin{array}{l}\text { Final earthworm biomass } \\
\text { (\% initial fresh biomass) }\end{array}$ & $\begin{array}{c}40.8(16.3) \\
*_{a}\end{array}$ & $\begin{array}{c}76.8(5.5) \\
b\end{array}$ & $\begin{array}{c}86.3(5.3) \\
b\end{array}$ & $\begin{array}{c}84.3(10.6) \\
a\end{array}$ & $\begin{array}{c}77.7(9.5) \\
a\end{array}$ & $\begin{array}{c}87.8(9.7) \\
\mathrm{a}\end{array}$ \\
\hline $\begin{array}{l}\text { Surface cast production } \\
\left(\mathrm{mg} \mathrm{g}^{-1} \text { day }^{-1}\right)\end{array}$ & $\begin{array}{c}28.6(21.0) \\
\mathrm{a}\end{array}$ & $\begin{array}{c}97.5(48.1) \\
\mathrm{ab}\end{array}$ & $\begin{array}{c}136.7(26.6) \\
b\end{array}$ & $\begin{array}{c}63.6(20.2) \\
\mathrm{a}\end{array}$ & $\begin{array}{c}109.7(73.8) \\
\mathrm{a}\end{array}$ & $\begin{array}{c}87.4(26.8) \\
\mathrm{a}\end{array}$ \\
\hline
\end{tabular}


Table 4

27 Burrow system characteristics by earthworm species and soil liming treatments. Metrics are means $(\mathrm{SD}, \mathrm{n}=3)$ with asterisks denoting 28 significantly different $(\mathrm{P}<0.05)$ earthworm treatments and letters denoting significantly different soil liming treatments within earthworm species 29 (t- or Welsh-tests).

\begin{tabular}{|c|c|c|c|c|c|c|}
\hline \multirow{2}{*}{$\begin{array}{l}\text { Species Treatment } \\
\text { Soil Treatment }\end{array}$} & \multicolumn{3}{|c|}{$\begin{array}{c}\mathrm{Tf} \\
\text { Anecic A.giardi }\end{array}$} & \multicolumn{3}{|c|}{$\begin{array}{c}\text { Tf } \\
\text { Endogeic } \text { A.caliginosa }\end{array}$} \\
\hline & $\begin{array}{l}\text { Non- } \\
\text { limed }\end{array}$ & $\begin{array}{r}\text { in situ } \\
\text { limed }\end{array}$ & $\begin{array}{l}\text { in vitro } \\
\text { limed }\end{array}$ & $\begin{array}{l}\text { Non- } \\
\text { limed }\end{array}$ & $\begin{array}{r}\text { in situ } \\
\text { limed }\end{array}$ & $\begin{array}{l}\text { in vitro } \\
\text { limed }\end{array}$ \\
\hline \multirow{2}{*}{$\begin{array}{l}\text { Burrow Abundance } \\
\text { (\#) }\end{array}$} & $12(6.0)$ & $21.7(4.0)$ & $26.7(10.5)$ & $62.3(16.0)$ & $51(16.5)$ & $66(4.0)$ \\
\hline & $* \mathrm{a}$ & $* \mathrm{a}$ & $\mathrm{a}$ & $\mathrm{a}$ & $\mathrm{a}$ & $\mathrm{a}$ \\
\hline \multirow{2}{*}{$\begin{array}{l}\text { OH horizon Burrow Length } \\
\text { (m) }\end{array}$} & $1.7(0.7)$ & $2.8(0.5)$ & $10.3(6.4)$ & $1.6(0.9)$ & $1.9(0.9)$ & $4.5(0.4)$ \\
\hline & $\mathrm{a}$ & $\mathrm{a}$ & $\mathrm{a}$ & $\mathrm{a}$ & $\mathrm{a}$ & $\mathrm{b}$ \\
\hline \multirow{2}{*}{$\begin{array}{l}\text { Total Burrow Length } \\
\text { (m) }\end{array}$} & $5.4(2.0)$ & $8.7(5.3)$ & $17.7(4.3)$ & $9.5(1.4)$ & $6.9(3.3)$ & $9.6(2.1)$ \\
\hline & $* \mathrm{a}$ & $a b$ & $* \mathrm{~b}$ & $\mathrm{a}$ & $\mathrm{a}$ & $\mathrm{a}$ \\
\hline \multirow{2}{*}{$\begin{array}{l}\text { Total Burrow Length per g Worm } \\
\text { ( } \mathrm{m} \mathrm{g}^{-1} \text { initial earthworm biomass) }\end{array}$} & $1.0(0.3)$ & $1.6(0.9)$ & $3.4(0.9)$ & $6.6(2.2)$ & $4.3(1.6)$ & $6.5(2.1)$ \\
\hline & $* \mathrm{a}$ & $\mathrm{a}$ & $\mathrm{b}$ & $\mathrm{a}$ & $\mathrm{a}$ & $\mathrm{a}$ \\
\hline \multirow{2}{*}{$\begin{array}{l}\text { Total Burrow Volume } \\
\left(\mathrm{cm}^{3}\right)\end{array}$} & $54.6(17.7)$ & $75.3(45.9)$ & $116.3(6.3)$ & $46.3(10.9)$ & $36.8(18.1)$ & $52.9(13.0)$ \\
\hline & $\mathrm{a}$ & $a b$ & $* \mathrm{~b}$ & $\mathrm{a}$ & $\mathrm{a}$ & $\mathrm{a}$ \\
\hline
\end{tabular}

